University of Wollongong

Research Online

Faculty of Engineering and Information

Faculty of Engineering and Information

Sciences - Papers: Part A

Sciences

$1-1-2013$

\title{
Effect of deformation temperature on niobium clustering, precipitation and austenite recrystallisation in a $\mathrm{Nb}$-Ti microalloyed steel
}

Andrii G. Kostryzhev

University of Wollongong, andrii@uow.edu.au

Abdullah Al Alshahrani

University of Wollongong, amfa065@uowmail.edu.au

Chen Zhu

University of Sydney, czhu@uow.edu.au

Simon P. Ringer

University Of Sydney

Elena V. Pereloma

University of Wollongong, elenap@uow.edu.au

Follow this and additional works at: https://ro.uow.edu.au/eispapers

Part of the Engineering Commons, and the Science and Technology Studies Commons

Research Online is the open access institutional repository for the University of Wollongong. For further information contact the UOW Library: research-pubs@uow.edu.au 


\title{
Effect of deformation temperature on niobium clustering, precipitation and austenite recrystallisation in a $\mathrm{Nb}$-Ti microalloyed steel
}

\author{
Abstract \\ The effect of deformation temperature on $\mathrm{Nb}$ solute clustering, precipitation and the kinetics of austenite \\ recrystallisation were studied in a steel containing $0.081 \mathrm{C}-0.021 \mathrm{Ti}-0.064 \mathrm{Nb}(\mathrm{wt} \%)$. Thermo-mechanical \\ processing was carried out using a Gleeble 3500 simulator. The austenite microstructure was studied \\ using a combination of optical microscopy, transmission electron microscopy, and atom probe \\ microscopy, enabling a careful characterisation of grain size, as well as Nb-rich clustering and \\ precipitation processes. A correlation between the austenite recrystallisation kinetics and the chemistry, \\ size and number density of $\mathrm{Nb}$-rich solute atom clusters, and $\mathrm{NbTi}(\mathrm{C}, \mathrm{N})$ precipitates was established via \\ the austenite deformation temperature. Specifically, we have determined thresholds for the onset of \\ recrystallisation: for deformation levels above $75 \%$ and temperatures above $825^{\circ} \mathrm{C}, \mathrm{Nb}$ atom clusters \\ recrystallisation

\section{Keywords} \\ recrystallisation, austenite, precipitation, clustering, niobium, ti, temperature, nb, deformation, effect, \\ microalloyed, steel

\section{Disciplines} \\ Engineering | Science and Technology Studies

\section{Publication Details} \\ Kostryzhev, A. G., Alshahrani, A. Al., Zhu, C., Ringer, S. P. \& Pereloma, E. V. (2013). Effect of deformation \\ temperature on niobium clustering, precipitation and austenite recrystallisation in a $\mathrm{Nb}$-Ti microalloyed \\ steel. Materials Science and Engineering A: Structural Materials: Properties, Microstructure and \\ Processing, 581 16-25.
}




\title{
Effect of deformation temperature on niobium clustering, precipitation and austenite recrystallisation in a $\mathrm{Nb}$-Ti microalloyed steel \\ Andrii G. Kostryzhev ${ }^{1}$, Abdullah Al Shahrani ${ }^{1}$, Chen Zhu ${ }^{2}$, Simon P. Ringer ${ }^{2}$, Elena V. Pereloma ${ }^{1}$ \\ 1 - School of Mechanical, Materials and Mechatronic Engineering, The University of Wollongong, NSW 2522, Australia \\ andrii@uow.edu.au, amfa065@uowmail.edu.au, elenap@uow.edu.au \\ 2 - Australian Centre for Microscopy and Microanalysis, and School of Aerospace, Mechanical and Mechatronic Engineering, The University of Sydney, NSW 2006, Australia chen.zhu@sydney.edu.au, simon.ringer@sydney.edu.au
}

\begin{abstract}
The effect of deformation temperature on $\mathrm{Nb}$ solute clustering, precipitation and the kinetics of austenite recrystallisation were studied in a steel containing $0.081 \mathrm{C}-0.021 \mathrm{Ti}-0.064 \mathrm{Nb}$ (wt. \%). Thermo-mechanical processing was carried out using a Gleeble 3500 simulator. The austenite microstructure was studied using a combination of optical microscopy, transmission electron microscopy, and atom probe microscopy, enabling a careful characterisation of grain size, as well as Nb-rich clustering and precipitation processes. A correlation between the austenite recrystallisation kinetics and the chemistry, size and number density of $\mathrm{Nb}$-rich solute atom clusters, and $\operatorname{NbTi}(\mathrm{C}, \mathrm{N})$ precipitates was established via the austenite deformation temperature. Specifically, we have determined thresholds for the onset of recrystallisation: for deformation levels above $75 \%$ and temperatures above $825{ }^{\circ} \mathrm{C}, \mathrm{Nb}$ atom clusters $<8 \mathrm{~nm}$ effectively suppressed austenite recrystallisation.
\end{abstract}

Keywords: Microalloyed steel; Nb precipitation kinetics; Austenite recrystallisation kinetics

\section{Introduction}

Grain refinement is one of the most technologically important strengthening mechanisms in ferritic steels, since a decrease in grain size leads generally to an increase in tensile strength and a decrease in ductile-to-brittle transition (DBTT) temperature [1]. During thermo-mechanical processing (TMP), the final ferrite grain size is largely governed by the prior austenite grain size. The austenite grain size is the result of competition between the driving forces for recrystallisation and grain growth, and grain boundary pinning by solute atoms and precipitates enabled by microalloy additions to the steel. The additions of $\mathrm{Nb}$ have been shown to significantly retard the austenite recrystallisation [2, 3]. However, the $\mathrm{Nb}$ pinning effect varies depending on whether the $\mathrm{Nb}$ atoms are clustered within the austenitic solid solution, or whether these solutes have nucleated as discrete second phase carbo-nitride precipitates; and the specific dispersive properties of these clusters and precipitates will have a key influence. Much research has been undertaken to investigate pinning effect arising from microalloy precipitates such as $\mathrm{Nb}(\mathrm{C}, \mathrm{N})$ or $\mathrm{NbC}$, much less has been reported on the optimum precipitate dispersion to control recrystallisation, and even less experimental evidence is available on the effects of $\mathrm{Nb}$-rich solute atom clusters on recrystallisation.

Earlier research, carried out on steels microalloyed with $0.01-0.1 \mathrm{Nb}$ (wt. \%) has shown an increase in the recrystallisation stop temperature, $\mathrm{T}_{\mathrm{nr}}$, indicating a retardation of recrystallisation as the $\mathrm{Nb}$ content of the steel increases [2]. The $\mathrm{Nb}(\mathrm{C}, \mathrm{N})$ precipitates were shown to pin grain 
boundaries more effectively than the $\mathrm{Nb}$ solute atoms [3, 4]. The maximum pinning force was reported for precipitates sized between 1 and $20 \mathrm{~nm}$ [5-7]. However, this pinning effect decreases with an increase in temperature, due to the decrease in particle number density following precipitate coarsening, coupled with higher driving forces for boundary migration. The influence of $\mathrm{Nb}$ on austenite recrystallisation at high temperature is considered to be predominantly due to solute drag $[3,4,8]$, and this effect is considered to be especially significant at low strain levels, short interpass times and high cooling rates [8-11], i.e. in those TMP conditions where recrystallisation is likely to take place prior to precipitation. It has also been found that the $\mathrm{Nb}$ precipitation kinetics (time, temperature and particle size) depend strongly on steel composition, in particular the $\mathrm{Nb}, \mathrm{Ti}, \mathrm{C}$ and $\mathrm{N}$ contents [2, 12-15], as well as strain levels [16-18]. An increased $\mathrm{Nb}$ and $\mathrm{N}$ content enhances $\mathrm{Nb}(\mathrm{C}, \mathrm{N})$ precipitation. The presence of Ti retards $\mathrm{Nb}(\mathrm{C}, \mathrm{N})$ precipitation, due to a decrease in $\mathrm{N}$ and $\mathrm{Nb}$ content following precipitation of $\mathrm{TiN}$ and $\mathrm{TiNb}-$ rich phases. With an increase in strain, the $\mathrm{Nb}$-rich precipitate size decreases, and the number density increases as a result of strain-induced precipitation on dislocations $[5,12,16]$. The straininduced precipitation retards recrystallisation by delaying recovery. However, when the particles become too fine, they are less effective at grain boundary pinning $[2,10]$. Therefore, the $\mathrm{Nb}$ pinning effect, and its influence on recrystalisation and grain growth, must be considered in terms of the steel composition and the TMP schedule.

In this paper, we explore the effect of $\mathrm{Nb}$ on austenite recrystallisation kinetics in a $\mathrm{Nb}-\mathrm{Ti}$ microalloyed steel deformed at three temperatures: above $\mathrm{T}_{\mathrm{nr}}$, near $\mathrm{T}_{\mathrm{nr}}$, and below $\mathrm{T}_{\mathrm{nr}}$. As austenite decomposition takes place on cooling to room temperature in carbon steels, it is not possible to evaluate the atomic distribution in austenite. Thus, all samples were water quenched immediately before or after the deformation in order to minimise the diffusion of substitutional elements. This approach enabled evaluation of the effect of deformation and temperature on the state of $\mathrm{Nb}$ before quenching. Characterisation of $\mathrm{Nb}$ clustering was performed using atom probe tomography (APT), which has proved to be a highly effective technique for investigation of finescale precipitation in steels [19-23]. The precipitation was studied using transmission electron microscopy (TEM). The $\mathrm{Nb}$ precipitate/cluster parameters and austenite microstructure have been shown to depend on deformation temperature and prior straining.

\section{Material and experimental techniques}

The Nb-Ti-microalloyed steel studied here was produced by BlueScope Steel Ltd and possessed composition $0.081 \mathrm{C}-1.20 \mathrm{Mn}-0.27 \mathrm{Si}-0.021 \mathrm{Ni}-0.019 \mathrm{Cr}-0.1 \mathrm{Mo}-0.016 \mathrm{Cu}-0.037 \mathrm{Al}-$ 0.064Nb-0.021Ti-0.003V-0.001S-0.012P-0.0047N (wt. \%). Samples 10x15x20 mm size were used for TMP simulations after cutting from the quarter thickness position of a $230 \mathrm{~mm}$ thick continuously cast slab. The TMP was carried out using a Gleeble 3500 thermo-mechanical simulator. The TMP schedule is summarized in Fig. 1 and involved: reheating for 5 min at 1250 ${ }^{\circ} \mathrm{C}$; roughing deformation up to 0.35 strain at $5 \mathrm{~s}^{-1}$ strain rate at $1100{ }^{\circ} \mathrm{C}$; cooling at $1{ }^{\circ} \mathrm{Cs}^{-1}$ to each of three deformation temperatures: 1075, 975 and $825{ }^{\circ} \mathrm{C}$, followed by either water quenching to room temperature (to preserve precipitate and cluster population prior to finishing deformation) or finishing deformation up to a strain of 0.75 at a strain rate of $5 \mathrm{~s}^{-1}$ and water quenching to room temperature (to observe influence of deformation on precipitation and cluster development). The water quenching resulted in cooling rate of about $200{ }^{\circ} \mathrm{Cs}^{-1}$, which allows to assume absence of any recrystallisation and precipitation during cooling. As noted earlier, the three finishing deformation temperatures of $1075{ }^{\circ} \mathrm{C}, 975{ }^{\circ} \mathrm{C}$ and $825{ }^{\circ} \mathrm{C}$ were selected to be 
respectively above, near and below the estimated recrystallization stop temperature $\left(\mathrm{T}_{\mathrm{nr}}\right)$ of $\sim 975$ ${ }^{\circ} \mathrm{C}$ [24]. Optical microscopy was carried out using a Leica DMRM microscope. The prior austenite grain boundaries were etched in a saturated solution of aqueous picric acid, hydrochloric acid and detergent for $5 \mathrm{~min}$ at $68{ }^{\circ} \mathrm{C}$. Austenite grain size was measured using the equivalent circle diameter technique. To obtain the grain size distributions, 800-1000 grains were imaged from the mid-thickness position of each TMP sample.

TEM of Nb-Ti-rich precipitates was carried out using carbon extraction replicas using a JEOL JEM2010 transmission electron microscope operating at $200 \mathrm{kV}$. For determination of the particle size distributions and the number density values $170-240$ particle were imaged for each TMP condition. The measurements were manually carried out using TEM micrographs covering the sample area of $39.6 \mu \mathrm{m}^{2}$ for each TMP condition. Precipitate compositions were determined using energy dispersive X-ray spectroscopy (EDS) point analysis on a Jeol TEM EDS system. For determination of the particle chemistries $20-25$ particles were analysed for each TMP condition. TEM observations of selected thin foil samples were carried out on a JEOL JEM2200FS field emission gun (FEG) TEM, using an accelerating voltage of $200 \mathrm{kV}$. The thin foil specimens were prepared by tripod polishing method and ion milling.

Atom probe specimens were prepared by the standard two-stage electropolishing technique [25]. Atom probe data was collected on a Cameca Local Electrode Atom Probe (LEAPTM), operating at a temperature of $20 \mathrm{~K}$ and a pulse fraction rate of $20 \%$ [26]. The results were carefully analysed and reconstructed using calibrated reconstruction parameters, determined by referring to spatial distribution maps from each individual data set [27]. The matrix composition was determined from the volumes free of visible solute atom segregation using background noise subtraction. The maximum separation envelope method [25, 28] was used to identify carbon segregation to dislocations, clusters and fine precipitates with $d_{\max }=1 \mathrm{~nm}$, and $d_{\max }=2 \mathrm{~nm}$ was used for evaluation of $\mathrm{Nb}$ clustering. A minimum of 20 atoms was used to discern $\mathrm{Nb}-\mathrm{C}$ clusters to minimize the influence of random fluctuations. However, in order to evaluate the solute drag effect of $\mathrm{Nb}$, cluster sizes starting from 2 atoms were analysed. The volumes selected for this analysis were free of visible carbon segregation. The Guinier radii, $r_{\mathrm{G}}$, of clusters/fine carbides were calculated from radii of gyration $\left(l_{\mathrm{g}}\right)$ data using the equation, $r_{\mathrm{G}}=\sqrt{ }(5 / 3) l_{\mathrm{g}}[25,28]$. Isoconcentration surfaces were also used for better visualisation of features of interest. Solute segregation to the boundaries was analysed using concentration profiles and Gibbsian Interfacial Excess (GIE) [25, 28].

\section{Results}

\subsection{TMP and optical study of microstructure}

As summarized in Fig. 2a, the stress-strain curves recorded during TMP exhibited continuous work hardening when the deformation temperature was $825^{\circ} \mathrm{C}$, and a period of work softening after a strain of about 0.5 when the deformation temperature was $1075{ }^{\circ} \mathrm{C}$. The stress-strain curve for the $975{ }^{\circ} \mathrm{C}$ deformation temperature shows an intermediate behavior such that the stress remains constant after a strain of $\sim 0.5$. The higher deformation temperature behavior can be attributed to the influence of dynamic recrystallisation (DRX): DRX takes place above the recrystallisation stop temperature, which was $\sim 975{ }^{\circ} \mathrm{C}$ for this steel [24]. The minimum point on the stress-strain curve second derivative dependence on stress refers to the critical stress value for the start of recrystallisation [29]. It is clear from Fig. 2b that the stress value was not high 
enough to initiate recrystallisation during deformation at $825^{\circ} \mathrm{C}$, whereas the DRX was not completed at $975^{\circ} \mathrm{C}$.

The quenched microstructures consisted of martensite, which was more refined after the deformation (Fig 3a and d). The prior austenite microstructures for samples quenched before deformation consisted of equiaxed grains (Fig. 3b and c). With a decrease in temperature, the average grain size increased, from $31 \pm 13 \mu \mathrm{m}$ for $1075{ }^{\circ} \mathrm{C}$ to $51 \pm 21 \mu \mathrm{m}$ for $975{ }^{\circ} \mathrm{C}$, due to an increase in cooling time from the roughing temperature of $1100{ }^{\circ} \mathrm{C}$. In the samples quenched after deformation at $1075{ }^{\circ} \mathrm{C}$, a fully recrystallised prior austenite microstructure was observed (Fig. 3e), with the average grain size decreasing to $9 \pm 4 \mu \mathrm{m}$. This corresponds to the work softening behavior observed during testing (Fig. 2b) and indicates that DRX occurred under these TMP conditions. In the samples quenched after deformation at $975{ }^{\circ} \mathrm{C}$, a mixture of recrystallised (equiaxed) and non-recrystallised (elongated) grains was observed (Fig. 3f), indicating partial recrystallisation. In the samples quenched after deformation at $825{ }^{\circ} \mathrm{C}$, all the grains were elongated indicating that the microstructure had not recrystallised. This is consistent with the work hardening behavior observed during testing (Fig. 2a).

\subsection{TEM study of precipitates}

The TEM imaging revealed the presence of $20-220 \mathrm{~nm}$ precipitates in all the studied samples (Figs. 4 and 5). The EDS data analyses enabled a distinction between various classes of precipitates: (i) coarse (>70 nm size) cuboidal Ti-rich and ellipsoidal Nb-rich carbonitrides (Fig. 6a-b); (ii) fine (<70 $\mathrm{nm}$ size) ellipsoidal $\mathrm{Nb}$-rich carbonitrides and sphere-like Ti-rich carbides (Fig. 6c-d). In some cases, the formation of a Nb-rich cap occurred heterogeneously on the Tirich core (Fig. 6e). The particle number density in the $<70 \mathrm{~nm}$ size group and a relative amount of $\mathrm{Nb}$-rich particles both increased after the deformation when compared to the non-deformed condition, and as the deformation temperature decreased (Table 1). This is likely due to an increase in TMP time. No significant variation in the particle parameters was observed in the > $70 \mathrm{~nm}$ size group. No significant variation in the average particle diameter with deformation temperature was observed. However, a slightly higher fraction of $<70 \mathrm{~nm}$ precipitates (Fig. 7) was present in the sample after deformation at $825^{\circ} \mathrm{C}$.

\subsection{APT study of atom clusters}

The APT data analyses has shown $\mathrm{C}$ segregation and $\mathrm{Nb}$ solute atom clustering in both nondeformed and deformed austenite, whereas the $\mathrm{Nb}-\mathrm{C}$ co-clustering was only in deformed austenite. In the samples quenched prior to deformation, the APT data revealed an enrichment of $\mathrm{C}$ in what were thought to be martensite lath boundaries and prior austenite grain boundaries (Fig. 8). Element concentration profiles across these two types of interfaces did not show any variation in the substitutional solute element distributions in the regions adjacent to these interfaces (Fig. 8b), suggesting that there was very little substitutional element diffusion on quenching. However, our GIE analysis of what was deduced to be a prior austenite grain boundary revealed a slight enrichment of all alloying elements, in particular $\mathrm{Nb}$ (Table 2, Boundary 1). In addition, a $\mathrm{C}$ and $\mathrm{Ti}$ rich precipitates were observed at the boundaries (Fig. 8c). The arrangement of $\mathrm{C}$ atoms in the samples quenched after deformation was similar to that of a lower bainite microstructure: formation of $\mathrm{C}$ atmospheres around dislocations and enrichment of $\mathrm{C}$ at grain boundaries was present, fine $\mathrm{Fe}$ carbides exhibited similar crystallographic orientations (Fig. 9). No detectable difference in the substitutional element concentration in the regions adjacent to either side of the grain boundary was observed, which is similar to the non- 
deformed condition. The GIE analysis revealed a depletion of $\mathrm{Nb}$ at the grain boundaries in deformed samples (Table 2, Boundary 2), which is in contrast to the measurements from samples in the non-deformed condition. The matrix analysis has shown a variation in $\mathrm{Nb}$ solute content in the range of $0.006-0.030$ at.\% for different TMP schedules, compared to 0.038 at. $\% \mathrm{Nb}$ according to the nominal steel composition. Although some depletion of $\mathrm{Nb}$ in solid solution was expected due to the formation of Ti-rich and $\mathrm{Nb}$-rich carbonitrides and carbides, the analysed volume contained very small clusters not apparent by simple inspection of the atom maps: these were detected and analysed using the maximum separation method.

For both non-deformed and deformed conditions, the number density of $\mathrm{Nb}$ clusters was observed to decrease as the cluster size increased (Fig. 10). The number density of small clusters (2-3 atoms per cluster) in non-deformed austenite was higher than in deformed austenite for both deformation temperatures of $1075{ }^{\circ} \mathrm{C}$ and $975{ }^{\circ} \mathrm{C}$ (Fig. $10 \mathrm{a}-\mathrm{b}$ ). The number density of intermediate sized clusters (4-8 atoms per cluster) was similar for both deformed and nondeformed conditions. However, the maximum cluster size was observed to be larger for the deformed condition compared to the non-deformed $\left(12\right.$ vs 8 atoms for $1075^{\circ} \mathrm{C}$ and 16 vs 11 atoms for $975^{\circ} \mathrm{C}$ ). With a decrease in deformation temperature from 1075 to 975 to $825^{\circ} \mathrm{C}$, the maximum cluster size increased respectively from 12 to 16 to 24 atoms. The total $\mathrm{Nb}$ cluster number density was measured to be slightly lower in the deformed samples $\left(3.19-3.81 \times 10^{7} \mu^{-}\right.$

${ }^{3}$ ) compared to the non-deformed ones $\left(4.27-4.38 \times 10^{7} \mu \mathrm{m}^{-3}\right)$, which may be related to the rearrangement of $\mathrm{Nb}$ clusters into $\mathrm{Nb}-\mathrm{C}$ clusters (see the data below). With a decrease in deformation temperature the cluster number density slightly increased.

The $\mathrm{Nb}-\mathrm{C}$ co-clusters of $5-8 \mathrm{~nm}$ (30-55 atoms) size were observed in deformed austenite (Fig. 11 and Table 3). The cluster composition varied with their size. After deformation at 1075 ${ }^{\circ} \mathrm{C}$ and $975{ }^{\circ} \mathrm{C}$ the $\mathrm{C}$ concentration in the clusters slightly increases with an increase in cluster size, which indicates a possibility of $\mathrm{C}$ diffusion to pre-existing $\mathrm{Nb}$ clusters. The trend is opposite for the $825^{\circ} \mathrm{C}$ sample: with an increase in cluster size the $\mathrm{Nb}$ content increased. Some clusters (Fig. 11, e) showed close to $50 / 50$ of $\mathrm{Nb} / \mathrm{C}$ content ratio, which corresponds to the composition of equilibrium $\mathrm{NbC}$ precipitate. However, these $\mathrm{Nb}-\mathrm{C}$ atom arrangements occurred within the Fe lattice, and no precipitate-like crystallographic orientation of these arrangements was observed. With a decrease in deformation temperature the $\mathrm{Nb}$ content in clusters increased, the average cluster size decreased and the number density increased. This corresponds to a decrease in $\mathrm{Nb}$ solubility and diffusion rate with a decrease in temperature.

\section{Discussion}

Austenite grain refinement took place after roughing deformation of 0.35 strain at $1100{ }^{\circ} \mathrm{C}$ as a result of recrystallisation. However, a longer time for grain growth was available on cooling to $975{ }^{\circ} \mathrm{C}$ finishing temperature, which resulted in a larger grain size compared to that for the sample quenched from $1075^{\circ} \mathrm{C}$. As seen from the TEM study, Ti was mostly consumed by coarse Ti nitrides and carbonitrides. The Ti-rich particles were formed upon solidification and remained undissolved during austenitising in Gleeble, due to a short reheating time. Presence of $\mathrm{Ti}$ in Nb-rich precipitates raised their solution temperature, compared to that of $\mathrm{Ti}$-free $\mathrm{Nb}$ carbonitrides [30]. Therefore, some large TiNb-rich particles were also observed in the quenched samples. Similar findings were reported for a variety of $\mathrm{Nb}$-containing thermo-mechanically processed steels [11, 31-34]. The remaining Ti precipitated as TiC, as found by APT in this work (Fig. 8c). With a decrease in finishing temperature the relative amount of $\mathrm{Nb}$ carbonitrides has 
increased (Table 1), due to an increase in cooling time (at a constant cooling rate of $1 \mathrm{Cs}^{-1}$ ) after roughing. This correlates well with the observed increase in the number density of $\mathrm{Nb}$ atom clusters and $\mathrm{Nb}$-rich precipitates in the $<70 \mathrm{~nm}$ size range (Table 6). Before the finishing deformation no interaction between $\mathrm{Nb}$ and $\mathrm{C}$ atoms was detected, as these elements were forming their own clusters. After the deformation at 1075 and $975^{\circ} \mathrm{C}$, the number density of $\mathrm{Nb}$ clusters decreased and that of $\mathrm{Nb}-\mathrm{C}$ clusters increased (Table 4), which can be a result of carbon pipe diffusion along dislocations to pre-existing $\mathrm{Nb}$ atom clusters. The $\mathrm{Nb}$ cluster, $\mathrm{Nb}-\mathrm{C}$ cluster and $\mathrm{Nb}$-rich precipitate number densities increased with a decrease in deformation temperature due to an increase in TMP time (time of cooling from the roughing to the finishing deformation temperature). This corresponds to the theoretically predicted and experimentally observed dependences of $\mathrm{Nb}$ precipitation kinetics on temperature [16, 17, 35, 36].

The recrystallisation kinetics during hot deformation is influenced by two competing processes: (i) generation of the new dislocations, leading to an increase in the stored energy and formation of subgrain structure and (ii) glide, climb and annihilation of the dislocations (recovery). The recovery of austenite is retarded by both solute $\mathrm{Nb}$ atoms and $\mathrm{Nb}$-rich precipitates [37, 38]. Although, the recrystallisation can be retarded by only precipitates of certain size and volume fraction [5-7, 39, 40]. Precipitates could play two roles with respect to recrystallisation: (i) interaction with dislocations during nucleation delaying recovery and (ii) interaction with moving grain boundaries [41, 42]. Using theoretical semi-quantitative model, Hutchinson et al. [7] have shown that $\mathrm{NbC}$ precipitates with $1-5 \mathrm{~nm}$ sizes are effective in retardation of recrystallisation for the industrial range of hot rolling temperatures above $900^{\circ} \mathrm{C}$, whereas at the temperatures below $900^{\circ} \mathrm{C}$ the solute drag effect might be more important. As observed in the present work, the number densities of $\mathrm{Nb}-\mathrm{C}$ clusters and $\mathrm{Nb}$-rich precipitates are low in the samples quenched from both temperatures of $1075{ }^{\circ} \mathrm{C}$ and $975{ }^{\circ} \mathrm{C}$ without deformation, which indicates a large amount of $\mathrm{Nb}$ remaining in solid solution after roughing. The prior austenite grain structure for these TMP conditions was fully recrystallised and the grain growth took place (Fig. 3b-c). This indicates that in the studied steel $\mathrm{Nb}$ in the form of solid solutes and $\mathrm{Nb}$ atom clusters (of 11 atom maximum size and $<4.4 \times 10^{7} \mu \mathrm{m}^{-3}$ number density) was unable to prevent recrystallisation and grain growth.

In the deformed samples the $\mathrm{Nb}-\mathrm{C}$ clustering / precipitation took place within 1-2 s during/after the deformation (time before water quench to room temperature), which is slightly quicker than might be expected from the literature data for similar steel chemistries $[2,12,13$, 15-18, 35]. This can be explained by the following. Formation of clusters is preferred at dislocation networks, such as nodes of dislocations, subgrain boundaries, grain boundaries and grain corners. Diffusion of $\mathrm{Nb}$ will be faster in these areas due to pipe or boundary diffusion, compared to volume diffusion. Strain level of 0.75 , applied during the second deformation pass, is relatively high, which should lead to the high dislocation density values after the deformation. However, the rate of dislocation annihilation and the mobility of grain boundaries both increase with an increase in temperature. Therefore, the precipitate number density observed after 1075 ${ }^{\circ} \mathrm{C}$ deformation was not high enough to pin the grain boundaries effectively and the recrystallisation proceeded. With a decrease in the deformation temperature to $975{ }^{\circ} \mathrm{C}$ the recovery slowed down. At the same time an increase in the $\mathrm{Nb}$ cluster size (up to 16 atoms), formation of $<8 \mathrm{~nm} \mathrm{Nb-C}$ clusters and an increase in the number density of the clusters and precipitates took place. As a result of the cluster/precipitate - grain boundary interaction the recrystallisation was retarded during the deformation at $975{ }^{\circ} \mathrm{C}$, which led to a partially recrystallised microstructure observed upon quenching. 
With a decrease in the deformation temperature to $825^{\circ} \mathrm{C}$ the $\mathrm{Nb}$ cluster and precipitate number density further increased, which had to result in an increase in the Nb pinning effect. High rate of dislocation structure accumulation, re-arrangement of which was hindered by the presence of fine clusters/precipitates, coupled with the reduced driving force for recrystallisation at low temperature led to the suppression of recrystallisation. It could be suggested that at these conditions, interaction of clusters $(<8 \mathrm{~nm}$ size) with dislocation substructure is the main operating mechanism during deformation and immediately after, as it is insufficient time for the strain-induced precipitates to grow. This is in disagreement with the model predictions that solute drag will be a dominant mechanism at temperatures $<900^{\circ} \mathrm{C}$ [7].

\section{Conclusions}

A detailed microstructural investigation of TMP Nb-Ti-microalloyed steel has shown the following:

1. At stress-strain-temperature conditions of DRX, the austenite recrystallisation can be rapidly completed within 1-2 s time period. With a decrease in deformation temperature, a higher level of deformation (higher stored energy) would be required to initiate dynamic recrystallisation.

2. $\mathrm{Nb}$ precipitation on pre-existing $\mathrm{TiN}$ particles, forms $(\mathrm{Ti}, \mathrm{Nb})(\mathrm{C}, \mathrm{N})$, decreasing the amount of $\mathrm{Nb}$ in solid solution and lowering the number density of $\mathrm{Nb}(\mathrm{C}, \mathrm{N})$ precipitation. In the Ti-microalloyed steels, this reduces the grain boundary pinning effect expected from $\mathrm{Nb}$ clustering or precipitation.

3. With a decrease in deformation temperature, the relative amount of $\mathrm{Nb}$-rich precipitates and the number density of $\mathrm{Nb}-\mathrm{C}$ clusters / precipitates increased, due to a decrease in $\mathrm{Nb}$ solubility in austenite and an increase in processing time.

4. $\mathrm{Nb}$ solute atom clusters did not suppress austenite recrystallisation and grain growth at a temperature of $1075^{\circ} \mathrm{C}$, which is above $\mathrm{T}_{\mathrm{nr}}$ for the studied steel.

5. $\mathrm{Nb}-\mathrm{C}$ solute atom co-clusters $<8 \mathrm{~nm}$ size range were shown to be effective to partially or fully suppress austenite recrystallisation at temperatures of $975^{\circ} \mathrm{C}$ and $825^{\circ} \mathrm{C}$, which are near and below $\mathrm{T}_{\mathrm{nr}}$ for the studied steel.

\section{Acknowledgements}

The authors are thankful to CBMM Technology Suisse SA, BlueScope Steel Ltd. and ARC (LP110100231) for financial support of the project. The authors are grateful for the scientific and technical assistance of the AMMRF (ammrf.org.au) at the University of Sydney, particularly Dr. Takanori Sato. A/Prof. Julie Cairney is thanked for fruitful discussions.

\section{References}

[1] D.T. Llewellyn, R.C. Hudd, Steels: metallurgy and application, Butterworth-Heinemann, Oxford, 1998.

[2] B. Dutta, C.M. Sellars, Mater. Sci. Tech. 3 (1987) 197 - 206.

[3] O. Kwon, A.J. DeArdo, Acta Metall. Mater. 39(4) (1991) 529 - 538.

[4] S. Vervynckt, K. Verbeken, P. Thibaux, M. Liebeherr and Y. Houbaert, ISIJ Int. 49(6) (2009) $911-920$. 
[5] S. Vervynckt, K. Verbeken, P. Thibaux, Y. Houbaert, Mat. Sci. Eng. A 528 (2011) 5519 5528.

[6] H.S. Zurob, G. Zhu, S.V. Subramanian, G.R. Purdy, C.R. Hutchinson and Y. Brechet, ISIJ Int. 45(5) (2005) $713-722$.

[7] C.R. Hutchinson, H.S. Zurob, C.W. Sinclair and Y.J.M. Brechet, Scripta Mat. 59 (2008) 635 $-637$.

[8] C.L. Miao, C.J. Shang, H.S. Zurob, G.D. Zhang, and S.V. Subramanian, Met. Mat. Trans. A 43 (2012) 665 - 676.

[9] W. P. Sun, M. Militzer, D. Q. Bai and J. J. Jonas, Acta Metall. Mater. 41(12) (1993) 3595 3604.

[10] R. Abad, A.I. Fernandez, B. Lopez and J.M. Rodriguez-Ibabe, ISIJ Int. 41(11) (2001) 1373 1382.

[11] A.J. DeArdo, Int. Mater. Rev. 48(6) (2003) 371 - 402.

[12] B. Dutta, E.J. Palmiere and C. M. Sellars, Acta Mat. 49 (2001) 785 - 794.

[13] Y. Xu, Y. Yu, X. Liu and G. Wang, J. Mater. Sci. Technol. 22(2), 2006149 - 152.

[14] A.C. Kneissl and P. Baldinger, J. Phys. IV, Suppl. J. Phys. III 3 (1993) 77 - 82.

[15] S. G. Hong, K.B. Kang and C.G. Park, Scripta Mat. 46 (2002) 163 - 168.

[16] S. Okaguchi and T. Hashimo, ISIJ Int. 32(3) (1992) 283 - 290.

[17] Y. Zeng and W. Wang, J. Mater. Sci. 43 (2008) 874 - 882.

[18] J.-S. Park, Y.-S. Ha, S.-J. Lee and Y.-K. Lee, Met. Mat. Trans. A 40 (2009) 560 - 568.

[19] E.V. Pereloma, K.F. Russell, M.K. Miller, I.B. Timokhina, Scripta Mat. 58 (2008) 1078 1081.

[20] I.B. Timokhina, M. Enomoto, M.K. Miller and E.V. Pereloma, Met. Mat. Trans. A 43(7) (2012) $2473-2483$.

[21] I.B. Timokhina, P.D. Hodgson, H. Beladi and E.V. Pereloma, La Metal. Italiana 101 (11-12) (2009) $43-48$.

[22] K. Y. Xie, L. Yao, C. Zhu, J. M. Cairney, C. R. Killmore, F. J. Barbaro, J. G. Williams and S. P. Ringer, Met. Mat. Trans. A 42 (2011) 2199 - 2206.

[23] K. Y. Xie, T. Zheng, J. M. Cairney, H. Kaul, J. G. Williams, F. J. Barbaro, C. R. Killmore and S. P. Ringer, Scripta Mat. 66 (2012) 710 - 713.

[24] A. Al Shahrani, T. Schambron, A. Dehghan-Manshadi, J. Williams, E. Pereloma, Mater. Sci. Forum 654-656 (2010) 298 - 301.

[25] B.G. Gault, M.P. Moody, J.M. Cairney, S.P. Ringer, Atom probe microscopy, Springer, New York, 2012.

[26] L. Yao, J.M. Cairney, C. Zhu, S.P. Ringer, Ultramicroscopy 111 (2011) 648 -651.

[27] M.P. Moody, B. Gault, L.T. Stephenson, D. Haley, S.P. Ringer, Ultramicroscopy 109 (2009) $815-824$.

[28] M.K. Miller, Atom probe tomography: analysis at the atomic level, Springer, New York, 2000.

[29] E. I. Poliak and J. J. Jonas, ISIJ Int. 43(5) (2003) 692 - 700.

[30] T. Gladman, The Physical Metallurgy of Micro-Alloyed Steels, The Institute of Materials London, 1997.

[31] E.V. Pereloma and J.D. Boyd, Mater. Sci. Tech. 12 (1996) 808 - 817.

[32] E.V. Pereloma, B.R. Crawford and P.D. Hodgson, Mat. Sci. Eng. A 299 (2001) 27 - 37.

[33] R.D.K. Misra, K.K. Tenneti, G.C. Weatherly, and G. Tither, Met. Mat. Trans. A 34 (2003) $2341-2351$. 
[34] A.J. Craven, K. He, L.A. Garvie, T.N. Baker, Acta Mat. 48 (2000) 3857 - 3868.

[35] B. Pereda, J. M. Rodriguez-Ibabe and B. López, ISIJ Int. 48 (2008) 1457 - 1466.

[36] Ya-bin Cao, Fu-ren Xiao, Gui-ying Qiao, Xiao-bing Zhang, Bo Liao, Mat. Sci. Eng. A 530 (2011) $277-284$.

[37] G. Engberg, Recovery in a Titanium Stabilized 15\%Cr-15\%Ni Austenitic Stainless Steel (TRITA MAC-98), Royal Institute of Technology; Stockholm, 1976.

[38] M. G. Akben, B. Bacroix and J. J. Jonas, Acta Metal. 31 (1983) 161 - 174.

[39] B. Dutta, E. Valdez, C.M. Sellars, Acta Metal. Mater. 40(4) (1992) 653 - 662.

[40] C.M. Sellars, Mater. Sci. Forum 284-286 (1998) 73 - 82.

[41] H.S. Zurob, C.R. Hutchinson, Y. Brechet, G. Purdy, Acta Mat. 50 (2002) 3075 - 3092.

[42] J. Liu and J.J. Jonas, Metal. Trans. A, 19 (1988) 1415 - 1424.

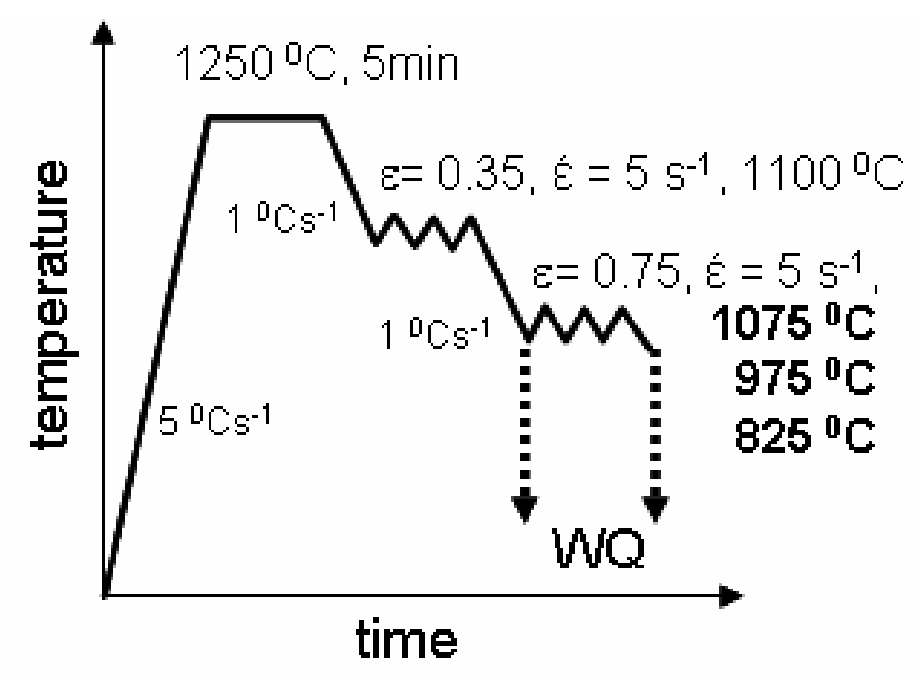

Fig. 1 Schematic diagram of thermo-mechanical processing
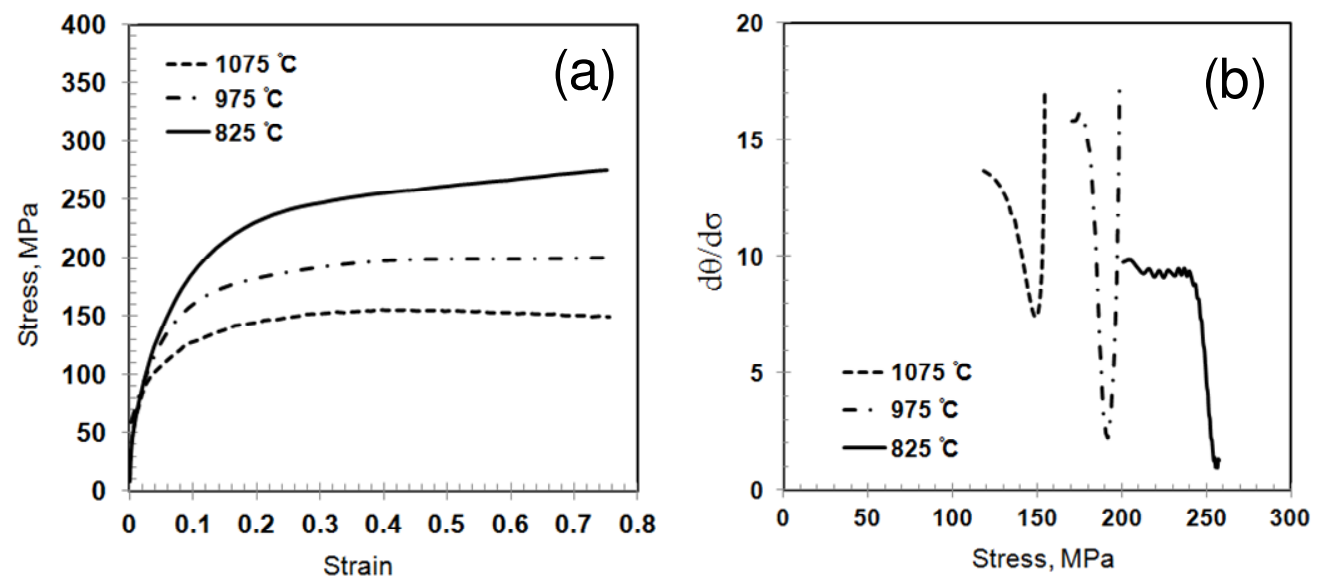

Fig. 2 (a) The compression stress-strain curves obtained during the TMP in Gleeble and (b) their second derivative dependences on stress 


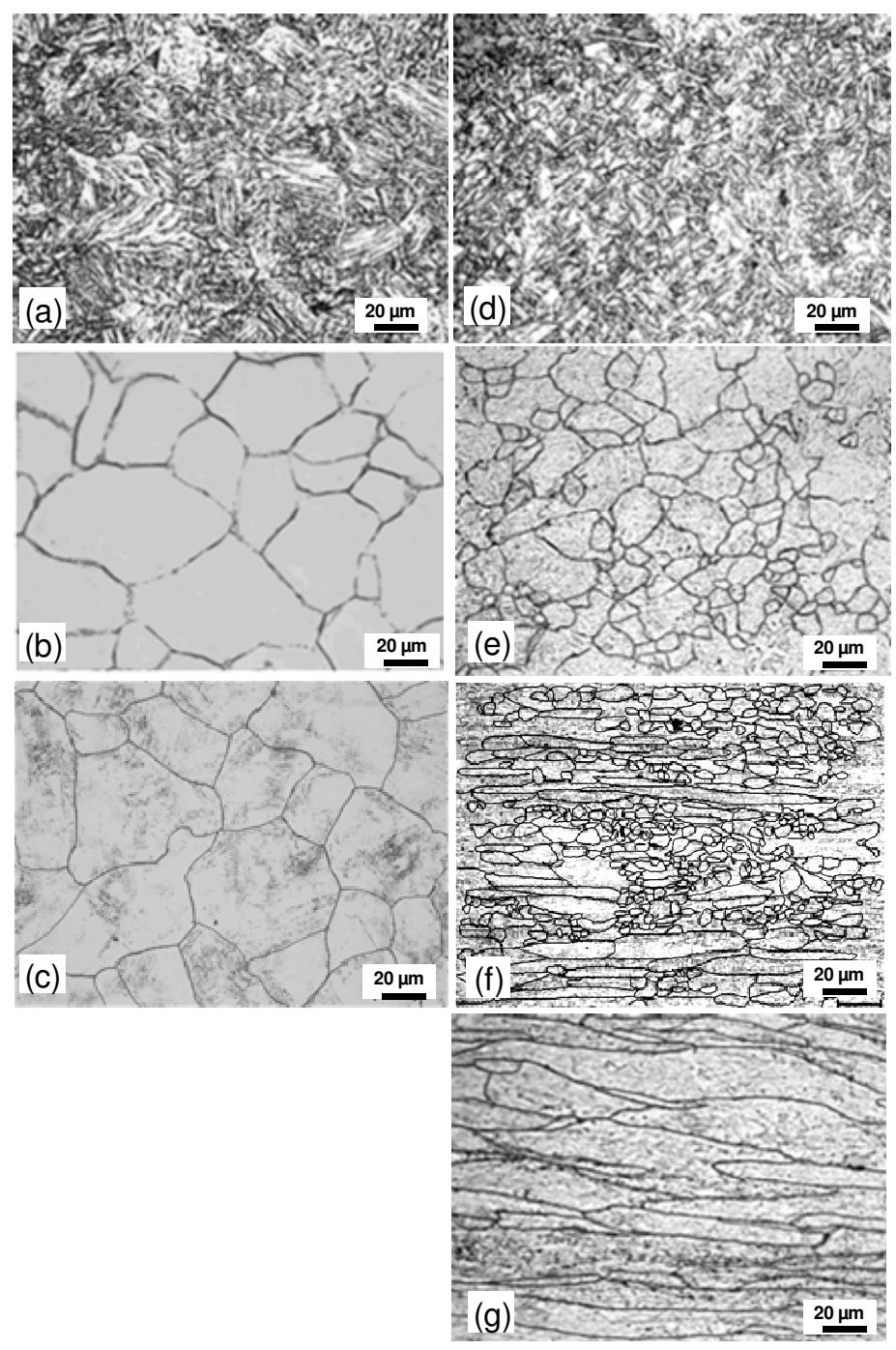

Fig. 3 Representative martensite misrostructures for $1075^{\circ} \mathrm{C}$ (a) before and (d) after deformation; and prior austenite microstructures for the samples quenched from (b) $1075^{\circ} \mathrm{C}$ and (c) $975^{\circ} \mathrm{C}$, and quenched after deformation at (e) $1075^{\circ} \mathrm{C}$, (f) $975^{\circ} \mathrm{C}$ and (g) $825^{\circ} \mathrm{C}$ 

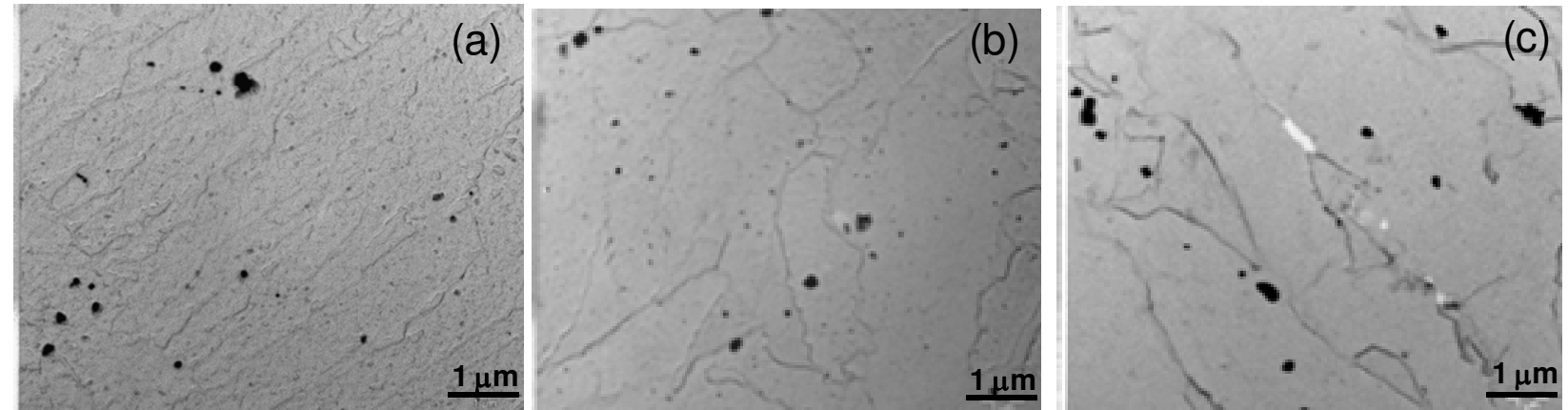

Fig. 4 Typical TEM micrographs of the Nb-Ti-rich precipitates in austenite for the (a) $1075{ }^{\circ} \mathrm{C}$, (b) $975{ }^{\circ} \mathrm{C}$ and (c) $825^{\circ} \mathrm{C}$ deformation temperatures (imaging of carbon replica samples)
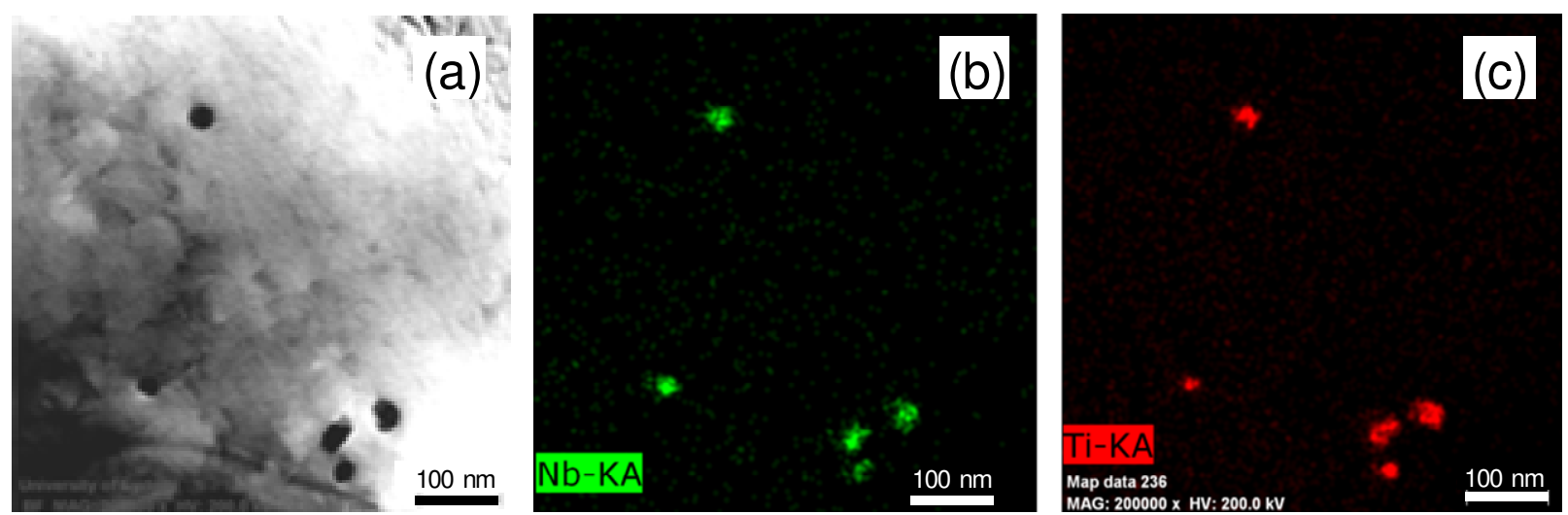

Fig. 5 Representative (a) STEM bright field image with corresponding EDS maps using (b) Nb and (c) Ti energy peaks for the sample deformed at $825^{\circ} \mathrm{C}$ 

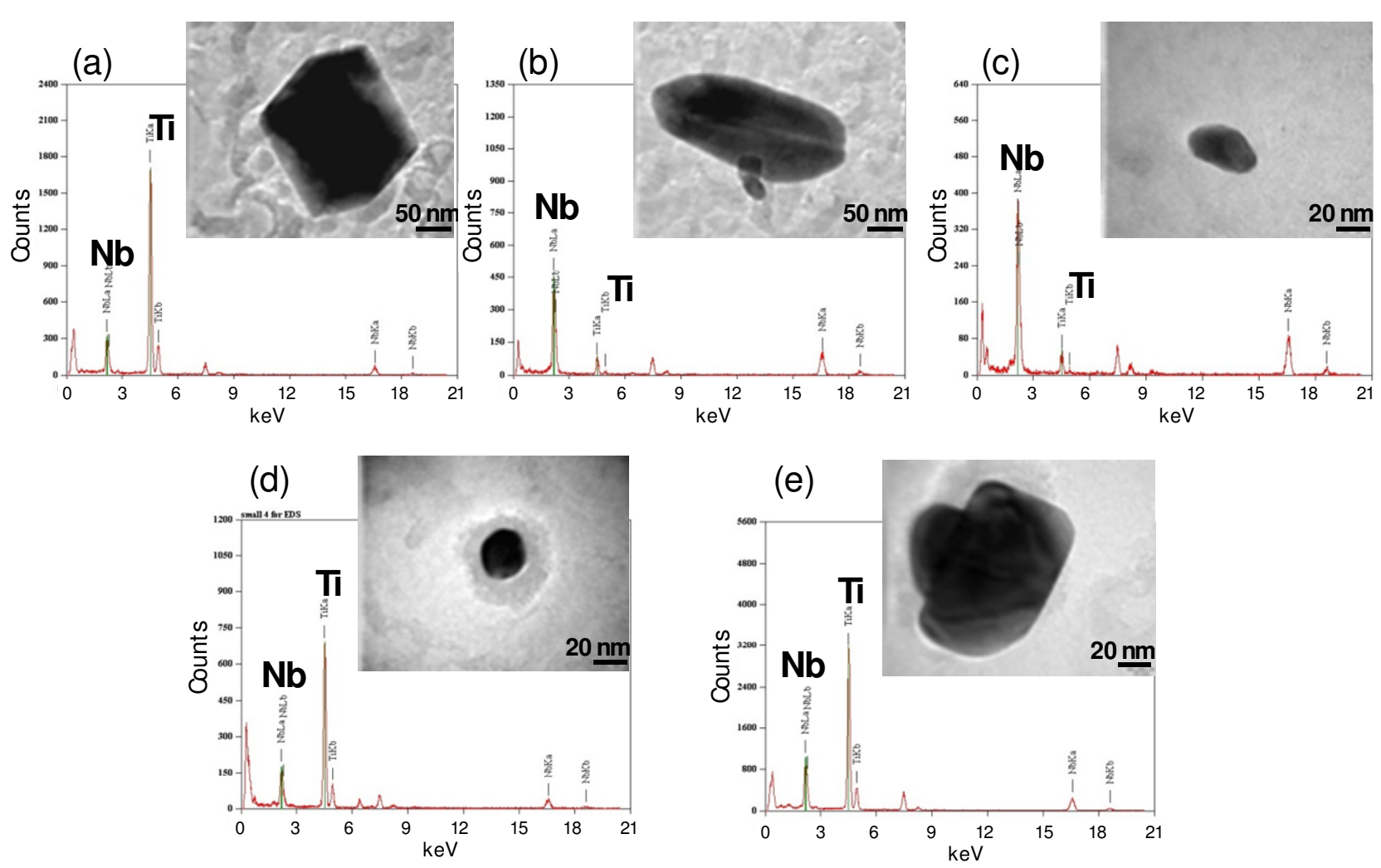

Fig. 6 Typical TEM micrographs and corresponding EDS spectra of a coarse (a) cuboidal Ti-rich and (b) ellipsoidal Nb-rich; and fine (c) ellipsoidal $\mathrm{Nb}$-rich and (d) spherical Ti-rich particles;

(e) a Nb-rich cap precipitation on the Ti-rich core

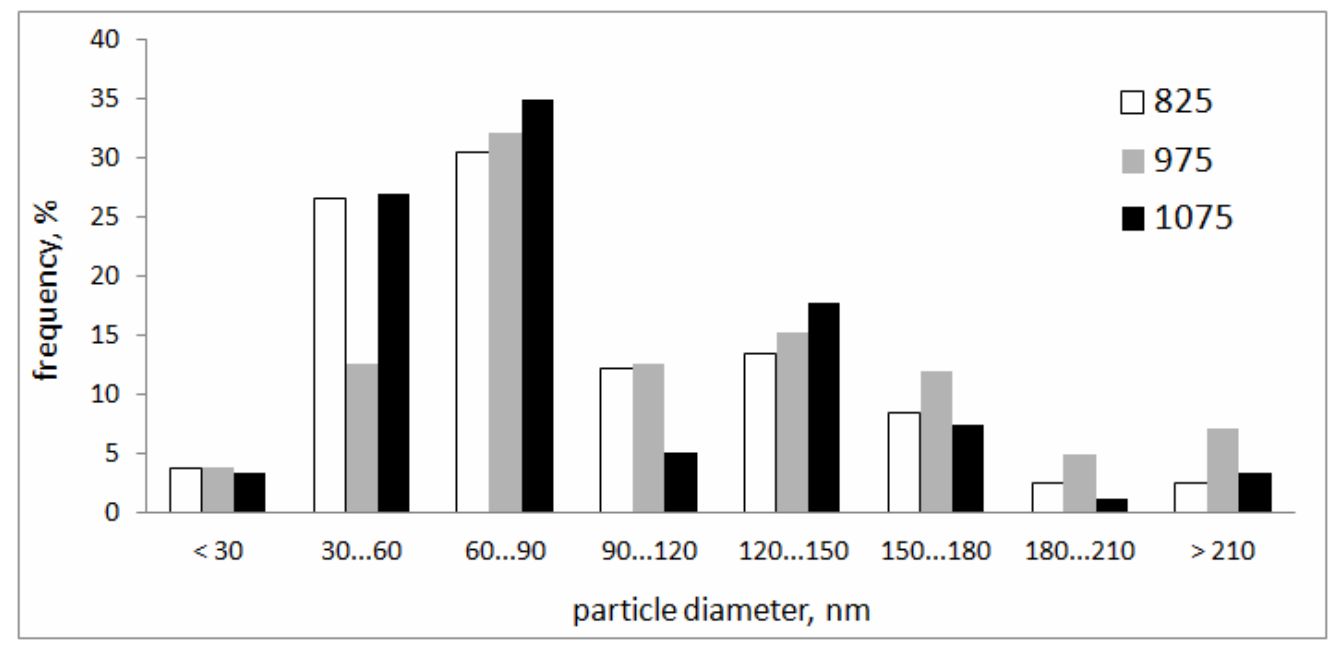

Fig. 7 The Nb-Ti-rich particle diameter distributions in deformed austenite 


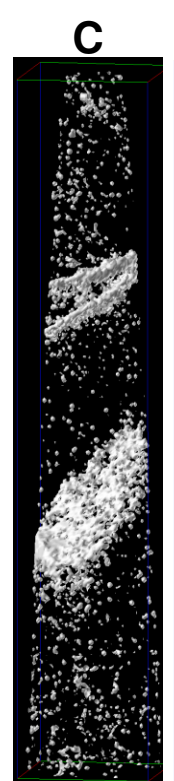

(a)
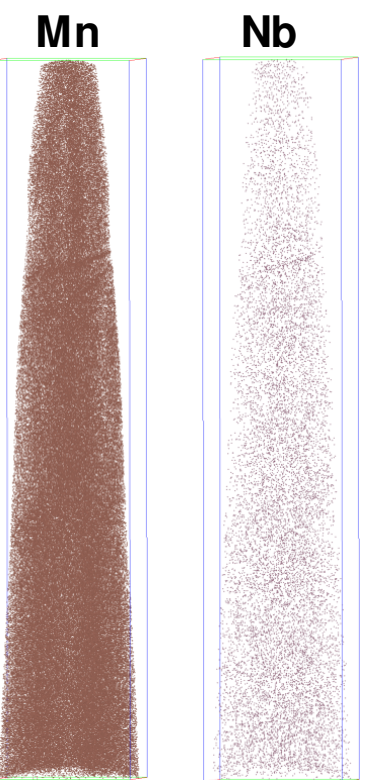

$\pi$

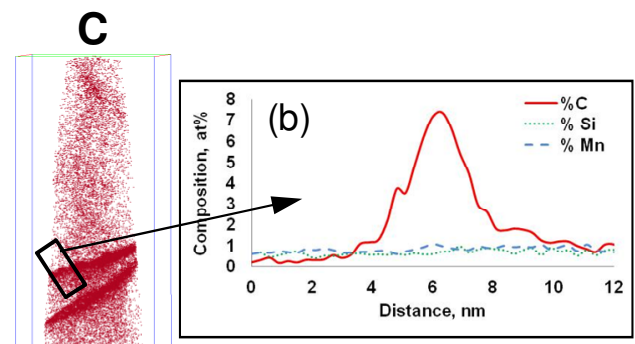

Fig. 8 (a) 2 at $\% \mathrm{C}$ iso-concentration surfaces, atom maps and element concentration profiles (b) across a grain boundary and (c) across a $\mathrm{TiC}$ precipitate for the samples quenched prior deformation at $1075^{\circ} \mathrm{C}$

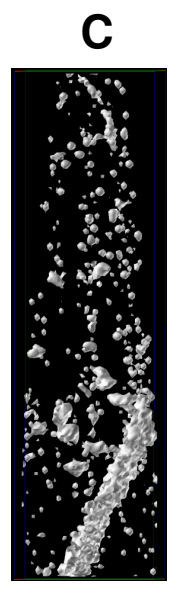

(a)
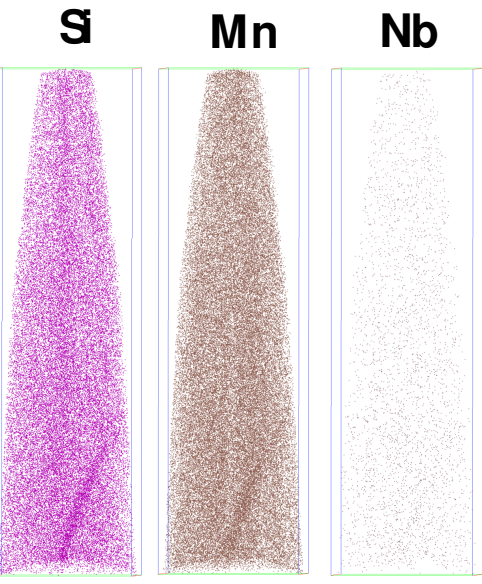

$\mathbf{N b}$

Tा

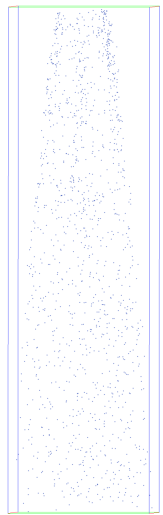

Fig. 9 (a) 2 at\% C iso-concentration surfaces, atom maps and element concentration profiles (b) across a grain boundary for the samples quenched after deformation at $1075^{\circ} \mathrm{C}$ 

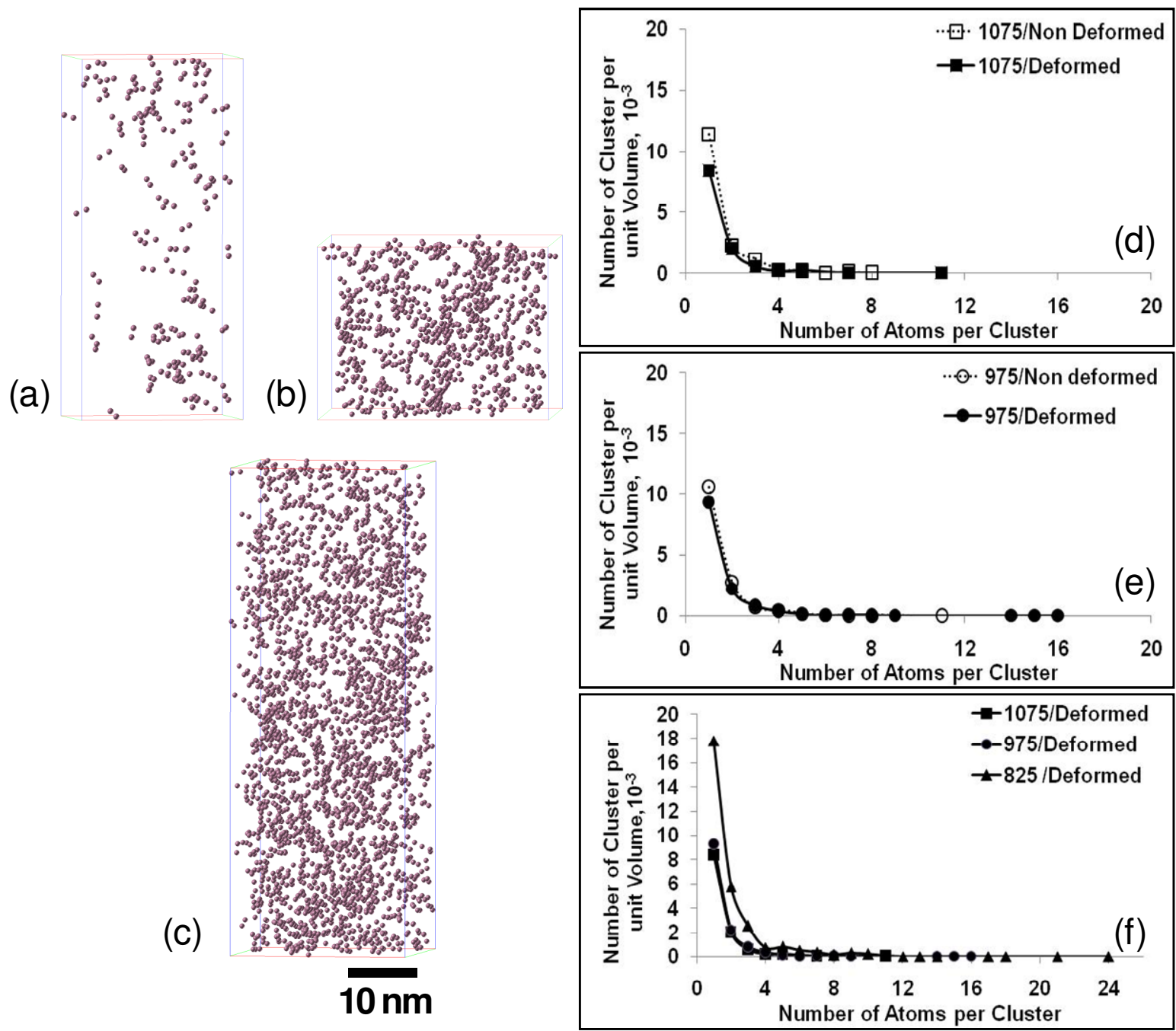

Fig. 10 Selected atom maps showing $\mathrm{Nb}$ clustering (all other atoms removed for clarity) for the samples deformed at (a) $1075^{\circ} \mathrm{C}$, (b) $975^{\circ} \mathrm{C}$ and (c) $825^{\circ} \mathrm{C}$; and the $\mathrm{Nb}$ cluster number density variations with cluster size: (d) and (e) show influence of straining at constant temperature, (f) shows influence of the deformation temperature. 


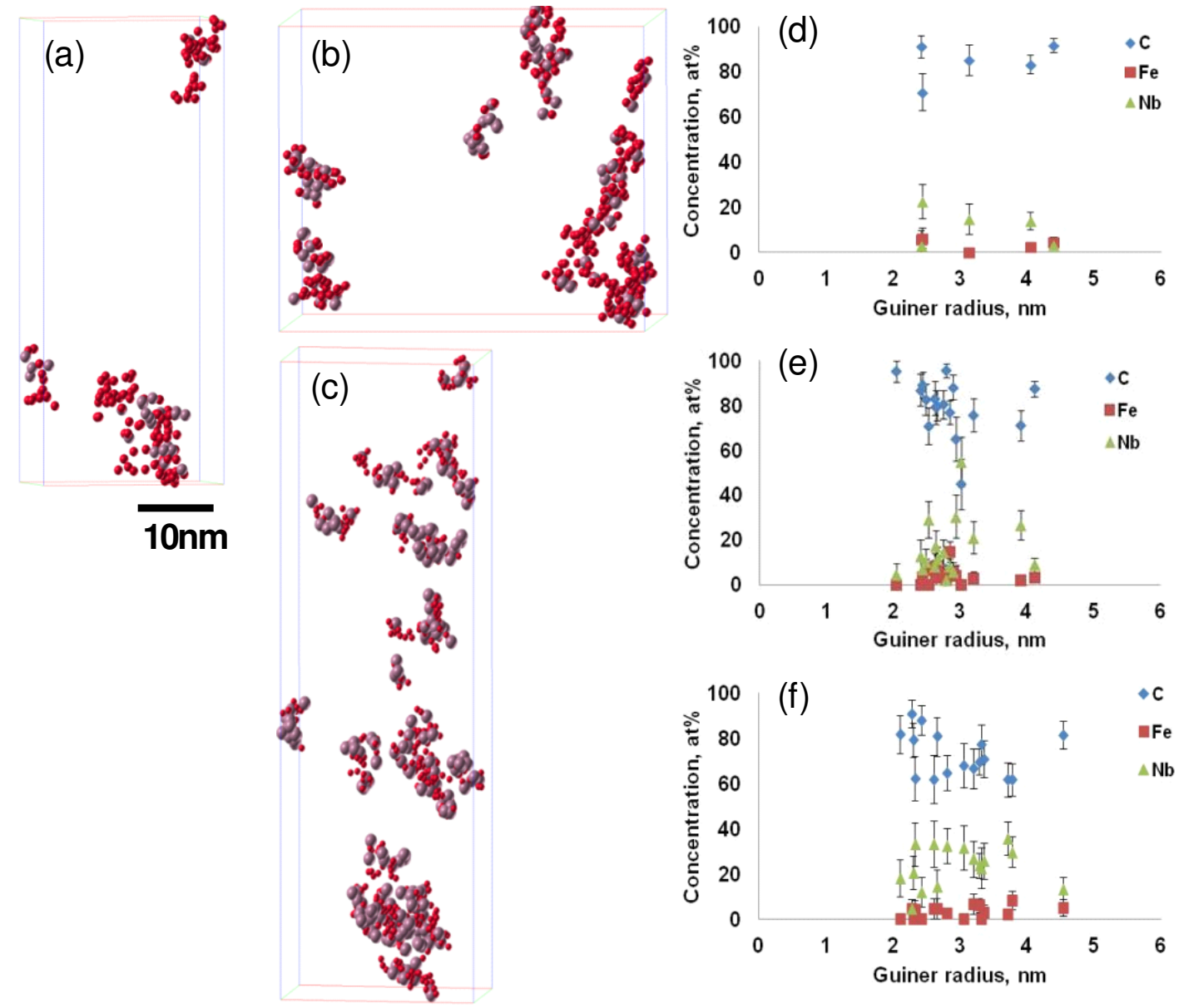

Fig. 11 Selected atom maps showing $\mathrm{Nb}-\mathrm{C}$ cluster arrangements (all other atoms removed for clarity) and the cluster composition variations with cluster size for the samples deformed at (a and d) $1075^{\circ} \mathrm{C}$, (b and e) $975^{\circ} \mathrm{C}$ and (c and f) $825^{\circ} \mathrm{C}$. 
Table $1 \mathrm{Nb}$-Ti-rich particle parameters

\begin{tabular}{|c|c|c|c|c|c|c|}
\hline \multirow[b]{2}{*}{$\begin{array}{c}\text { Temperature, } \\
{ }^{\circ} \mathrm{C}\end{array}$} & \multicolumn{3}{|c|}{ Geometry } & \multicolumn{3}{|c|}{ Composition } \\
\hline & $\begin{array}{c}\text { size range, } \\
\mathrm{nm}\end{array}$ & $\begin{array}{c}\text { number } \\
\text { density, } \mu \mathrm{m}^{-2}\end{array}$ & $\begin{array}{c}\text { average } \\
\text { diameter, } \mathrm{nm}\end{array}$ & chemistry & shape & $\%$ \\
\hline \multirow{4}{*}{$\begin{array}{c}1075{ }^{\circ} \mathrm{C} \\
\text { quenched }\end{array}$} & \multirow{2}{*}{$>70$} & \multirow{2}{*}{0.18} & \multirow{2}{*}{$94 \pm 21$} & Ti rich $+\mathrm{Nb}$ & $\square$ & 87 \\
\hline & & & & $\mathrm{Nb}$ rich $+\mathrm{Ti}$ & 0 & 13 \\
\hline & \multirow{2}{*}{$<70$} & \multirow{2}{*}{0.05} & \multirow{2}{*}{$60 \pm 8$} & Ti rich $+\mathrm{Nb}$ & $\square$ & 100 \\
\hline & & & & $\mathrm{Nb}$ rich $+\mathrm{Ti}$ & - & 0 \\
\hline \multirow{4}{*}{$\begin{array}{c}975^{\circ} \mathrm{C} \\
\text { quenched }\end{array}$} & \multirow{2}{*}{$>70$} & \multirow{2}{*}{0.15} & \multirow{2}{*}{$117 \pm 30$} & Ti rich $+\mathrm{Nb}$ & $\square$ & 84 \\
\hline & & & & $\mathrm{Nb}$ rich $+\mathrm{Ti}$ & 0 & 16 \\
\hline & \multirow{2}{*}{$<70$} & \multirow{2}{*}{0.05} & \multirow{2}{*}{$62 \pm 7$} & Ti rich $+\mathrm{Nb}$ & $\square$ & 67 \\
\hline & & & & $\mathrm{Nb}$ rich $+\mathrm{Ti}$ & 0 & 33 \\
\hline \multirow{4}{*}{$\begin{array}{l}1075^{\circ} \mathrm{C} \\
\text { deformed }\end{array}$} & \multirow{2}{*}{$>70$} & \multirow{2}{*}{0.12} & \multirow{2}{*}{$130 \pm 37$} & $\mathrm{Ti}$ rich $+\mathrm{Nb}$ & $\square 0$ & 77 \\
\hline & & & & $\mathrm{Nb}$ rich $+\mathrm{Ti}$ & 0 & 23 \\
\hline & \multirow{2}{*}{$<70$} & \multirow{2}{*}{0.11} & \multirow{2}{*}{$51 \pm 13$} & $\mathrm{Ti}$ rich $+\mathrm{Nb}$ & $\square 0$ & 87 \\
\hline & & & & $\mathrm{Nb}$ rich $+\mathrm{Ti}$ & 0 & 13 \\
\hline \multirow{4}{*}{$\begin{array}{c}975{ }^{\circ} \mathrm{C} \\
\text { deformed }\end{array}$} & \multirow{2}{*}{$>70$} & \multirow{2}{*}{0.10} & \multirow{2}{*}{$144 \pm 41$} & Ti rich $+\mathrm{Nb}$ & $\square 0$ & 80 \\
\hline & & & & $\mathrm{Nb}$ rich $+\mathrm{Ti}$ & 0 & 20 \\
\hline & \multirow{2}{*}{$<70$} & \multirow{2}{*}{0.14} & \multirow{2}{*}{$54 \pm 15$} & Ti rich $+\mathrm{Nb}$ & $\square 0$ & 50 \\
\hline & & & & $\mathrm{Nb}$ rich $+\mathrm{Ti}$ & 0 & 50 \\
\hline \multirow{4}{*}{$\begin{array}{c}825^{\circ} \mathrm{C} \\
\text { deformed }\end{array}$} & \multirow{2}{*}{$>70$} & \multirow{2}{*}{0.17} & \multirow{2}{*}{$131 \pm 36$} & Ti rich $+\mathrm{Nb}$ & $\square$ & 92 \\
\hline & & & & $\mathrm{Nb}$ rich $+\mathrm{Ti}$ & 0 & 8 \\
\hline & $<70$ & 016 & 50. & Ti rich $+\mathrm{Nb}$ & $\square$ & 7 \\
\hline & & & & $\mathrm{Nb}$ rich $+\mathrm{Ti}$ & 0 & 73 \\
\hline
\end{tabular}

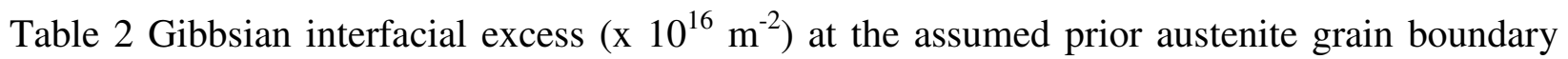
before deformation (Boundary 1) and after deformation (Boundary 2)

\begin{tabular}{|c|c|c|}
\hline Element & Boundary 1 & Boundary 2 \\
\hline $\mathrm{Al}$ & $-0.7 \pm 0.7$ & $85 \pm 16$ \\
\hline $\mathrm{C}$ & $254 \pm 6.5$ & $3600 \pm 65$ \\
\hline $\mathrm{Fe}$ & $-309 \pm 35$ & $-4400 \pm 430$ \\
\hline $\mathrm{Nb}$ & $1 \pm 0.2$ & $-40 \pm 2.9$ \\
\hline $\mathrm{Mo}$ & $2.5 \pm 0.8$ & $5.2 \pm 10$ \\
\hline $\mathrm{P}$ & $-1.5 \pm 0.4$ & $43 \pm 9.6$ \\
\hline $\mathrm{Si}$ & $7.8 \pm 3$ & $670 \pm 43$ \\
\hline $\mathrm{Mn}$ & $35 \pm 3.8$ & $62 \pm 42$ \\
\hline $\mathrm{V}$ & $-0.7 \pm 0$ & $-4 \pm 2.4$ \\
\hline $\mathrm{Ni}$ & $8.9 \pm 1.2$ & $59 \pm 26$ \\
\hline $\mathrm{Cr}$ & $5 \pm 1$ & $44 \pm 9.8$ \\
\hline $\mathrm{Ti}$ & $0.7 \pm 0.1$ & $1.7 \pm 3.3$ \\
\hline
\end{tabular}


Table 3 Characterisation of $\mathrm{Nb}-\mathrm{C}$ clusters in the deformed austenite

\begin{tabular}{|c|c|c|c|c|c|c|}
\hline \multirow{2}{*}{$\begin{array}{l}\text { Deformation } \\
\text { temperature, } \\
{ }^{\circ} \mathrm{C}\end{array}$} & \multicolumn{3}{|c|}{ Element concentration, at $\%$} & \multirow{2}{*}{$\begin{array}{c}\text { Guinier } \\
\text { radius, } \\
\mathrm{nm}\end{array}$} & \multirow{2}{*}{$\begin{array}{l}\text { Number of } \\
\text { atoms in } \\
\text { cluster }\end{array}$} & \multirow{2}{*}{$\begin{array}{l}\text { Number } \\
\text { density, } \\
\times 10^{5} \mu \mathrm{m}^{-3}\end{array}$} \\
\hline & $\mathrm{C}$ & $\mathrm{Fe}$ & $\mathrm{Nb}$ & & & \\
\hline \multirow{3}{*}{1075} & $70.9 \pm 8.2$ & $6.5 \pm 4.4$ & $22.6 \pm 7.5$ & 2.4 & 29 & \multirow{3}{*}{1.8} \\
\hline & $84.3 \pm 5.6$ & $1.3 \pm 0.9$ & $14.5 \pm 5.4$ & $3.6 \pm 0.5$ & $52 \pm 35$ & \\
\hline & $91.5 \pm 4.0$ & $5.3 \pm 3.2$ & $3.2 \pm 2.5$ & $3.4 \pm 1.1$ & $57 \pm 35$ & \\
\hline \multirow{2}{*}{975} & $63.1 \pm 9.0$ & $1.6 \pm 1.6$ & $35.3 \pm 8.9$ & $3.1 \pm 0.5$ & $29 \pm 11$ & \multirow{2}{*}{1.9} \\
\hline & $84.7 \pm 5.7$ & $5.0 \pm 3.2$ & $10.3 \pm 5.0$ & $2.76 \pm 0.5$ & $36 \pm 17$ & \\
\hline \multirow{3}{*}{825} & $50.1 \pm 8.7$ & $5.9 \pm 2.8$ & $44.0 \pm 8.6$ & $3.1 \pm 0.1$ & $31 \pm 1$ & \multirow{3}{*}{2.1} \\
\hline & $65.2 \pm 8.2$ & $3.6 \pm 2.7$ & $31.2 \pm 8.0$ & $3.6 \pm 0.3$ & $33 \pm 8$ & \\
\hline & $76.2 \pm 6.7$ & $4.8 \pm 3.1$ & $19.0 \pm 6.2$ & $3.4 \pm 0.9$ & $46 \pm 33$ & \\
\hline
\end{tabular}

Table 4 Influence of a TMP schedule on the $\mathrm{Nb}$ precipitation and austenite recrystallisation

\begin{tabular}{|c|c|c|c|c|}
\hline \multirow[b]{2}{*}{ TMP condition } & \multicolumn{3}{|c|}{ Number density } & \multirow[b]{2}{*}{$\begin{array}{l}\text { Austenite } \\
\text { condition }\end{array}$} \\
\hline & $\begin{array}{c}\mathrm{Nb} \\
\text { clusters, } \\
\mathrm{x} 10^{7} \mu \mathrm{m}^{-3}\end{array}$ & $\begin{array}{c}\mathrm{Nb}-\mathrm{C} \\
\text { clusters, } \\
\times 10^{5} \mu \mathrm{m}^{-3}\end{array}$ & $\begin{array}{c}\text { Nb-rich } \\
\text { particles } \\
<70 \mathrm{~nm}, \mu \mathrm{m}^{-2}\end{array}$ & \\
\hline $1075^{\circ} \mathrm{C}$ quenched & 4.27 & no & 0 & $\begin{array}{c}\begin{array}{c}\text { recrystallised + } \\
\text { grain growth }\end{array} \\
\end{array}$ \\
\hline $975^{\circ} \mathrm{C}$ quenched & 4.38 & no & 0.03 & $\begin{array}{l}\text { recrystallised+ } \\
\text { grain growth }\end{array}$ \\
\hline $1075^{\circ} \mathrm{C}$ deformed & 3.19 & 1.8 & 0.11 & DRX \\
\hline $975^{\circ} \mathrm{C}$ deformed & 3.74 & 1.9 & 0.14 & partial DRX \\
\hline $825^{\circ} \mathrm{C}$ deformed & 3.81 & 2.1 & 0.16 & pancaked, no DRX \\
\hline
\end{tabular}

